\title{
The Effectiveness of Poetry Appreciation Textbook for Character Education Implementation at Higher Education
}

\section{Oktaviani Windra Puspita}

Doctorate Student in University of Sebelas Maret, Indonesia, okta89pwd@gmail.com

\section{Andayani}

Prof., University of Sebelas Maret Surakarta, Indonesia, bu_anda09@yahoo.co.id

\section{Herman J. Waluyo}

Prof., University of Sebelas Maret Surakarta, Indonesia, herman.jwaluyo@yahoo.co.id

\section{Muhammad Rohmadi}

Dr., University of Sebelas Maret Surakarta, Indonesia, rohmadi_dbe@yahoo.com

The study aims to find out the effectiveness of poetry appreciation textbook for the implementation of character education values at the Higher Education institution. It was set in four universities, two of which are located in Central Java, including University of Sebelas Maret Surakarta and University of Muhammadiyah Purworejo meanwhile; the other two are in Special Region of Yogyakarta, including University of Ahmad Dahlan, and University of Sarjanawiyata Taman Siswa. It utilized an experimental method with Independent Sample T-Test based on the mean difference of pre-test and post-test results from the control and experimental group. The finding confirms that the experimental group obtained the average score that equals 15.68 , meanwhile the control group obtained 10.86 . The T-Test shows tcalc $=5.087(\mathrm{p}=0.000<0.05)$, that rejects the Null Hypothesis. It concludes that there is a significant difference between the experimental and control group in the use poetry appreciation textbook for character education implementation at the Higher Education institution. The study expects further exploration concerning character education implementation through literature works in a wider range for the sake of research and development. The uniqueness of the textbook in combining the values of personal development and literature is recommended as the dominant feature to introduce a complex gradual learning system for the innovation of teaching and learning method.

Keywords: effectiveness, textbook, poetry appreciation, values, character education implementation, higher education

Citation: Puspita, O. W., Andayani, Waluyo, H. J., \& Rohmadi, M. (2019). The Effectiveness of Poetry Appreciation Textbook for Character Education Implementation at Higher Education. International Journal of Instruction, 12(1), 685-700. https://doi.org/10.29333/iji.2019.12144a 


\section{INTRODUCTION}

The current lecture concerning poetry appreciation in Higher Education often generates less comprehension among students. It happens due to the complex features of poetry as a literary product that requires a high skill of analysis (Daniel, 2013). The phenomenon derives from several interconnecting factors within the learning environment, which include the students, lecturers, methods, and textbooks.

The conveying of the subject using the conventional method will normally attract less attention, as it cannot effectively lead them to dive into the meaningful learning process. It even generates ignorance among learners, for instance, they prefer accessing their cellular phones to listening to their lecturers (Noel, Daniels, \& Martins, 2015). The method also often fails in developing a constructive learning atmosphere, and sometimes causes the discrepancy of analytical thinking competencies. In contrast, the constructive learning model is better for self-exploration and learning control that will shape the connection between the past and current knowledge (Koohang, Riley, Smith, \& Schreurs, 2009).

In a few times, lecturers also utilize random textbooks and ignore the contextual teaching principles for poetry appreciation subject. Meanwhile, a contextual approach offers an effective process in improving the students' learning outcome (Satriani, Emilia, \& Gunawan, 2012). The spontaneous material exploration only leads to unclear learning purposes due to students' low understanding, in addition to the inappropriate method. The lack of instruments will leave them run in place without any attempt to establish neither inquiry cycle nor peer-to-peer learning.

The article focuses on the poetry appreciation lecture that utilizes a textbook as the primary instrument. It proposes a strategy in maximizing the learning process for poetry appreciation through several procedures, which include improving the learning model, encouraging students' motivation, and developing the learning media. The notion underlies the development of the poetry appreciation textbook that features a communicative discussion as the essential need to afford success in a learning process, from where a digital learning will offer more effective breakthrough compared to the conventional learning model (Lin, Chen, \& Sheng Liu, 2017). Relating to the notion, a textbook is supposed as a crucial facility that will define the success of poetry appreciation lecture, the lecturers should be capable in selecting the most appropriate one in representing their subjects and heading to an in-depth learning cycle (Topalov \& Radic-Bojanic, 2016).

A textbook is an essential means to boost an effective learning process. It should offer several specific features as a learning instrument, which include theoretical and practical guidelines, exercises for interactive discussion, grammatical references, syllabus, reflection, and lecture supports (Cunningworth, 2000). It functions to enrich the knowledge, either in national or global range (Rifai, 2010). Regardless its position as a non-formal instrument, the existence of textbook offers a crucial feature to enlarge the range of students' competencies, especially for poetry appreciation subject (Erin Katheleen, 2010). Relating to the urgent demand of a textbook as a learning instrument, 
an evaluation is also required to ensure a series of its impact on the students' comprehension (Tomilson, Dat, Masuhara, \& Rubdy, 2001).

Poetry appreciation is a symbolization of honor to its intrinsic values about morality. The value interpretation through logical reasoning and transcription will potentially boost students to grow their passion in the literary world as the reflection of the reality that spans in their daily life (Sayuti, 2010). The poetic sense of literary works also helps readers to comprehend life as it is.

The success on poetry appreciation lecture will offer a broader development to the implementation of character education that generally contains the basic principles of attitude, which include humbleness, kindness, honesty, tolerance, trust, integrity, loyalty, justice, freedom, equity, and respects (Brooks, 2001). (Hoge, 2002) defined it as a conscious attempt to uplift individual excellent characters. As this article emphasizes on the discussion of character education through poetry appreciation, it requires an appropriate textbook as the instrument that should contain at least six functions, which include: 1) representation of syllabus in formulating the learning guidelines and outcomes; 2.) accommodation of students' expectation in following learning process securely; 3.) visualization of practical activities in developing the range of discussion and activities; 4.) evaluation of study; 5.) additional support for learning activities in the forms of teaching guidelines, worksheets, and videos; and 6.) consistency of learning programs based on students' grade ((Bastrukmen, 2010; Graves, 2000).

It utilizes the most current poetry appreciation textbook developed through the implementation of character education. The textbook offers seven features, which include: 1.) theoretical reviews; 2.) strata of poetry appreciation; 3.) variations of poetries; 4.) values of character education in each poetry; 5.) poetry creation; 6.) poetry recreation; and 7.) evaluation. With its constructive features as one unit is linked with the others, the textbok also provides the students with an easy stage of comprehension

Previously, (Kirkgoz, 2008) had deployed poetries as the effective means for EFL students in improving their Linguistics competence. In contrast, this article studies the use of poetry appreciation subject in implementing the values of character education. It is parallel with (Bodenhorn \& Skaggs, 2006) who held the similar study for four years, of which was capable to measure the level of character education implementation among the students, lecturers, and administrators at the Higher Education level. It is also similar to (Mohammad \& Kumari, 2007) who identified the Science textbook at public Pakistani schools aiming to improve a practical learning model.

Based on those previous studies, the article offers a new coverage that emphasizes on the urgency of poetry appreciation textbook as the instrument of character education implementation at the Higher Education level. The study was set in four universities located in Central Java and Special Region of Yogyakarta, of which the samples were divided into the control and experimental group. It aims to prove the textbook effectiveness for a new learning instrument that spans not only in academic range, but also the development of exemplary characters. 


\section{THEORITICAL REVIEW}

\section{Poetry Appreciation Textbook}

A textbook is one of the necessary teaching instruments that may influence the notion about national cultures and cultural disputes (Pingel, 2010). (Brown, 2001) defined it as a supporting material in developing complex activities within the learning process. It helps lecturers to improve the standard learning environment and encourage students to construct their knowledge effectively. It provides primary and secondary materials in more various forms, including videos, photos, texts, and other media. However, most of the readers prefer primary materials on their textbook due to the discussion of their socio-cultural background, meanwhile secondary materials normally only contain daily reports, such as papers and magazines (Richards, 2001).

The arrangement of a textbook should involve the education experts in attempt to create a counterbalance to the primary learning instruments issued by the Department of Education. It is crucial to help lecturers stay on the track and focus on the development of interactive learning process. An ideal textbook should contain at least six functions, including: 1) representation of syllabus in formulating the learning guidelines and outcomes; 2) accommodation of students' expectation in following learning process securely; 3) visualization of practical activities in developing the range of discussion and activities; 4) evaluation of study; 5) additional support for learning activities in the forms of teaching guidelines, worksheets, and videos; and 6) consistency of learning programs based on students' grade (Bastrukmen, 2010; Graves, 2000).

In particular, a poetry appreciation textbook mainly introduces the art of literature through the comprehension of its poetic messages. The process may run through several activities, including listening, reading, interpretation, recitation, and reviews by engaging academic activities, creativity, and self-motivation (Waluyo, 2002). Through the composition of dictions and rhythm that generates a wondrous sense of emotion, poetry may feature self-expression through language and culture (Hunter, 2000). It stimulates human to dive into their unconsciousness and follow the expression of its author's imagination through the interpretation of both physical and spiritual structures of the Linguistics study (Waluyo, 2010). Therefore, it represents as an effort to honor the literary work by comprehending its intrinsic and extrinsic values as the reflection for the daily life circulation.

\section{Character Education}

The essence of character education was firstly renown in the United States in the 1600s (Vardin, 2003). The term thrived at public schools and initiated the idea of a contextual approach in the education field at the end of 1800 (Howard, Berkowitz, \& Achaeffer, 2004). However, its implementation is currently decreasing due to the change in the political trends that lead to a heavy challenge of its survival.

It shapes people with the ethics codes in a wise manner. With the main coverage at the psychological state, it relates the implementation of morality in speech, manner, and action to teach the future generation on how to differentiate goodness and badness. The 
outcome will potentially encourage them to risk their life in maintaining the sublime values that they believe as the truth (Lickona, 2013). Its nuance will lead them to grow their logical competence by holding the principles of morality as their life guidance. Its concept consists of three elements, which include notion (cognitive), morality (affective), and courage (psychomotor) that appear as a unity (Creasy, 2008). Those elements will shape a total quality management for the educational institutions in several terms, which include teaching and learning atmosphere, partnership, leadership, curriculum, and even home-schooling system (Battistich, 2003; Bier \& Berkowitz, 2004; Greenberg et al., 2003; Leming, 2000; L. H. Schultz \& Selman, 2004; Lynn Hickey Schultz, Barr, \& Selman, 2001; Stetson, Hurley, \& Miller, 2003)

The term 'character' generally refers to a specific connotation that points out a public understanding of the interrelating factors of attitude. The notion is comprehended by the phrase 'the better someone attitude is, the more excellent he is' in the aspects of trustworthiness, integrity, passion, responsibility, and reliability (Pike, 2017). It affirms that character education is the implementation of moral values that aims to uphold the values of knowledge and enable human to establish a Divine connection and mundane communication.

(Megawangi, 2004) stated that character education consists of nine pillars, which include: 1) religiosity; 2) independence and responsibility; 3) honesty and wisdom; 4) respect and politeness; 5) generosity; 6) confidence, creativity, and hard work; 7) leadership and justice; 8) humbleness; and 9) tolerance, fairness, and unity. The pillars are the essential core of personality development conveyed through a learning model called knowing the good, feeling the good, and acting the good. In contrast, (Pusat Kurikulum, 2010) identified 18 values, which include: 1) religiosity; 2) honesty; 3) tolerance; 4) discipline; 5) hard work; 6) creativity; 7) independent; 8) democracy; 9) curiosity; 10) nationalism; 11) patriotism; 12) respect; 13) friendliness; 14) fairness; 15) fond of reading; 16) environmental awareness; 17) social awareness; and 18) responsibility.

Meanwhile, the textbook examined in this study briefly extracts seven core values of character education, which include: 1) religiosity; 2) patriotism; 3) democracy; 4) nationalism; 5) honesty; 6) socio-culture awareness; and 7) hard work. Those values are universally considered as the core of implementation. It will guide the students not only to comprehend the literary aspects, but also grow themselves in an excellent manner through the application of those noble values.

\section{METHOD}

\section{Research Design}

The study deployed an experimental method with the non-equivalent before-after design to examine the textbook effectiveness in implementing the character education through poetry appreciation. Its procedures refer to the concepts proposed by Gall, Gall, \& Borg (Cohen, Manion, \& Morrison, 2000), including: 1) measuring the instrument validity as the dependent variable that relates to the students' capability in comprehending the character education values through poetry appreciation; 2) dividing the participants into 
two groups (control and experimental group) based on the score classification; 3) formulating different treatments for both groups; 4) measuring the independent variable by analyzing the score difference of both groups; and 5) comparing the results.

The textbook effectiveness is examined by giving different treatments for the control and experimental group. The lecturer utilized the old textbook and Powerpoint presentation as the learning instruments for the control group. In this procedure, the lecturer explained the theoretical reviews of the subject in a detail point of view and shared academic tasks. Meanwhile, the experimental group earned more complex treatment through the utilization of the new textbook. Table 1 illustrates the design.

Table 1

Non-equivalent before-after design

\begin{tabular}{lccl}
\hline \multicolumn{2}{c}{ Quasi-experimental Designs } & Treatment & \multicolumn{1}{c}{ Remark } \\
\hline $\begin{array}{l}\text { Non-equivalent } \\
\text { (before) design }\end{array}$ & control-group & $\mathrm{O} 1 \mathrm{X} 1 \mathrm{O} 2$ & $\mathrm{O} 1=$ pre-test \\
$\begin{array}{l}\text { Non-equivalent } \\
\text { group (after) design }\end{array}$ & experimental- & & $\begin{array}{l}\mathrm{O} 2=\text { post-test } \\
\mathrm{X} 1=\text { utilizing conventional textbook }\end{array}$ \\
\hline
\end{tabular}

\section{Sampling Technique}

It adopted a simple random sampling technique that (Kelinger, 2006) explained as a withdrawal for a number of samples by considering that every individual has the same proportion of being selected. It randomly decides the samples from the population as the subject of study.

\section{Sample}

It involved four universities located in Central Java and Special Region of Yogyakarta as the samples, including: 1) University of Sebelas Maret Surakarta; 2) University of Muhammadiyah Purworejo; 3) University of Ahmad Dahlan Yogyakarta; and 4)

University of Sarjanawiyata Taman Siswa Yogyakarta. Those universities utilized the different textbook for poetry appreciation lecture.

Meanwhile, the population consisted of 221 students who had registered in the poetry appreciation lecture for the academic year of 2016/2017. The students were classified into two groups, of whom 114 students belonged to the control group and the other 107 students belonged to the experimental group.

To afford the efficiency, this study also involved four poetry appreciation lecturers from those universities. Two among the lecturers took a part in conveying the lecture for the control group, meanwhile the other two for the experimental group. The strategy aimed to create a collaborative influence among the researchers and lecturers, especially for further discussion on the subject development.

\section{Instrument}

The instrument consisted of 60 multiple choice questions concerning the values of character education contained in the poetries. However, the number of questions 
decreased after validity and reliability test. The instrument eventually consisted of 50 multiple choice questions in total.

The questions were arranged in a sequence of: 1) making the question boundary based on the textbook contents; 2) embedding the values of character education, which include religiosity, patriotism, democracy, nationalism, honesty, socio-culture awareness, and hard work; 3) arranging the questions in a five-option multiple choice model; 4) testing the instrument validity and reliability; 5) rearranging the valid and reliable questions in a sequence of points.

The instrument arrangement has several indicators, which include poetry definition, elements, variations, genre, strata, character education and its values, aims of poetry appreciation, oral and written poetic expression, musicalization, character implementation, the essence of character education through poetry creation, and evaluation of poetry creation.

\section{Instrument Validity and Reliability}

A validity test aims to ensure the instrument properness based on the aims of the research. This study firstly used content validity to determine the appropriateness of the questions based on the academic purpose (Djali \& Muljono, 2008) and secondly deployed the Pearson Product Moment Correlation with the significance level $=0.05$ to find out the item validity.

All of the valid items then proceeded to the reliability tests to define the instrument over-time consistency (Djali \& Muljono, 2008). It also used the Pearson Product Moment Correlation to calculate the value of its reliability.

The instrument consisted of 60 points of questions previously. However, the validity test affirmed that there were 10 invalid items, therefore the instrument contained 50 points of questions in total. The next procedure was classifying those items based on content differentiating criteria and difficulty level (Sukardi, 2008). Based on the content differentiating criteria, the instrument consisted of 0 points of excellent questions; 50 points of fair questions; and 10 points of poor questions. Meanwhile, based on the difficulty level, the instrument consisted of 24 points of easy questions; 36 points of intermediate questions; and 0 points of difficult questions.

The reliability test utilized the Cronbach's Alpha formula. The calculation generated $r_{\text {calc }}=0.972$. The result was compared to $r_{\text {tab }}=0.444$ at $\mathrm{df}=20$ and $5 \%$ significance level. As the value of $r_{\text {calc }}>r_{\text {tab }}(0.972>0.444)$, the instrument is reliable.

\section{Data Collecting Technique}

The study used observation and test as the data collecting techniques. The observation aims to obtain the real condition of the research subject, meanwhile the test aims to find out the students' comprehension to character education values through the discussion of poetry appreciation. The test consisted of 50 points of multiple-choice questions by the assessment indicators of 0 point for the incorrect answer and 1 point for the correct answer. 


\section{Data Analysis}

The data analysis fell into several procedures, including: 1) pre-test and post-test session for the control and experimental group; of which pre-test aims to define both groups' initial competence, meanwhile post-test aims to find out the difference between those groups after the treatment; 2) normality test to find out the data distribution; 3) homogeneity test to find out the data variance between the control and experimental group; and 4) Independent Sample T-Test to find out the data significance between the two groups.

\section{FINDINGS}

\section{Pre-Test Scores and Pos-Ttest Scores}

The control group consisting of 114 students obtained the average score of pre-test = 51.82 with the value of standard deviation $=9.918$ and the average score of post-test $=$ 62.68 with the value of standard deviation $=9.905$. Meanwhile, the experimental group consisting of 107 students obtained the average score of pre-test $=50.41$ with the value of standard deviation $=8.829$ and the average score of post-test $=66.09$ with the value of standard deviation $=10.310$. Table 2 shows the detail of pre-test and post-test results from both groups.

Table 2

Pre-test and post-test of result of control and experimental group

\begin{tabular}{llllll}
\hline Group & $\mathrm{N}$ & $\begin{array}{l}\text { Pre-test } \\
\text { Mean }\end{array}$ & Std. Deviation & $\begin{array}{l}\text { Post-test } \\
\text { Mean }\end{array}$ & $\begin{array}{l}\text { Std. } \\
\text { Deviation }\end{array}$ \\
\hline Control & 114 & 51.82 & 9.918 & 62.68 & 9.905 \\
Experimental & 107 & 50.41 & 8.829 & 66.09 & 10.310 \\
\hline
\end{tabular}

The treatment for the control group utilized conventional textbook, meanwhile the experimental group utilized the new textbook that contains character education.

\section{Normality Test}

The normality test aims to determine the type of data distribution as the initial requirement for statistical analysis before proceeding to the T-Test. At the Normality Test, the data are considered to have a normal distribution if the value of sig $>0.05$. Otherwise, the data are not distributed normally. Table 3 and 4 show the detail of calculation.

Table 3

Normality test for pre-test

\begin{tabular}{|c|c|c|c|c|c|c|c|}
\hline & \multirow[t]{2}{*}{ Research group } & \multicolumn{3}{|c|}{ Kolmogorov-Smirnov(a) } & \multicolumn{3}{|c|}{ Shapiro-Wilk } \\
\hline & & Statistic & df & Sig. & Statistic & Df & Sig. \\
\hline Pretest & Control & .075 & 114 & .142 & .976 & 114 & .036 \\
\hline Score & Experimental & .076 & 107 & .151 & .988 & 107 & .456 \\
\hline
\end{tabular}

a Lilliefors Significance Correction

At the pre-test session, the experimental group obtained the Kolmogorov-Smirnov statistic value $=0.075$ with $\mathrm{sig}=0.142>0.05$. The result confirmed a normal data 
distribution. Meanwhile, the control group obtained the statistic value $=0.076$ with $\mathrm{sig}=$ $0.151>0.05$ that confirmed a normal data distribution as well.

Table 4

Normality test for pos-test

\begin{tabular}{|c|c|c|c|c|c|c|c|}
\hline & \multirow[t]{2}{*}{ Research Group } & \multicolumn{3}{|c|}{ Kolmogorov-Smirnov (a) } & \multicolumn{3}{|c|}{ Shapiro-Wilk } \\
\hline & & Statistic & df & Sig. & Statistic & Df & Sig. \\
\hline \multirow[t]{2}{*}{ Posttest Score } & Control & .064 & 114 & $.200(*)$ & .980 & 114 & .079 \\
\hline & Experimental & .074 & 107 & .190 & .981 & 107 & .141 \\
\hline
\end{tabular}

* This is a lower bound of the true significance.

\section{a Lilliefors Significance Correction}

At the post-test session, the experimental group obtained the Kolmogorov-Smirnov statistic value $=0.064$ with $\mathrm{sig}=0.200>0.05$. The result confirmed a normal data distribution. Meanwhile, the control group obtained the statistic value $=0.074$ with $\mathrm{sig}=$ $0.190>0.05$ that confirmed a normal data distribution as well.

\section{Homogeinity Test}

The homogeneity test aims to determine the data variance of the control and experimental group as the initial requirement for statistical analysis before proceeding to the T-Test. At the Homogeneity Test, the data are considered to have a homogeneous variance if the value of sig $>0.05$. Otherwise, the data are heterogeneous. Table 5 and 6 show the details of calculation.

Table 5

$\underline{\text { Homogeneity test for pre-test }}$

\begin{tabular}{llrrrr}
\hline & & Level & \multirow{2}{*}{ df1 } & df2 & Sig. \\
\hline Pretest & Based on Mean & 2.932 & 1 & 219 & .088 \\
Score & Based on Median & 2.808 & 1 & 219 & .095 \\
& Based on Median and with adjusted df & 2.808 & 1 & 218.960 & .095 \\
& Based on trimmed mean & 2.909 & 1 & 219 & .089 \\
\hline
\end{tabular}

The homogeneity test at the pre-test session resulted from the Levene Statistic value = 2.932. It confirmed the value of $\operatorname{sig}=0.088>0.05$. Therefore, the pre-test scores of the control and experimental group have homogeneous variance.

Table 6

Homogeinity test for post-test

\begin{tabular}{llllll}
\hline & & Level Statistic & df1 & df2 & Sig. \\
\hline Posttest & Based on Mean & .002 & 1 & 219 & .966 \\
score & Based on Median & .001 & 1 & 219 & .977 \\
& Based on Median and with & .001 & 1 & 216.00 & .977 \\
& adjusted df & & & 7 & .967 \\
& Based on trimmed mean & .002 & 1 & 219 & .965 \\
\hline
\end{tabular}


The homogeneity test at the post-test session resulted from the Levene Statistic value = 0.002 . It confirmed the value of $\operatorname{sig}=0.966>0.05$. Therefore, the post-test scores of the control and experimental group have homogeneous variance.

\section{Hypothesis Test}

The hypothesis test applies an Independent Sample T-Test to find out the mean difference between the control and experimental group. At the Hypothesis Test, the Null Hypothesis is accepted if the value of sig $>0.05$. Otherwise, the Null Hypothesis is rejected. Table 7 and 8 show the details of calculation.

Table 7

Independent samples t-test for pre-test score difference

\begin{tabular}{|c|c|c|c|c|c|c|c|c|c|c|}
\hline \multicolumn{4}{|c|}{ Level's Test for Equality of Variances } & \multicolumn{7}{|c|}{ t-test for Equality of Means } \\
\hline & & $\mathrm{F}$ & Sig. & $\mathrm{t}$ & df & $\begin{array}{l}\text { Sig. (2- } \\
\text { tailed) }\end{array}$ & $\begin{array}{l}\text { Mean } \\
\text { Difference }\end{array}$ & $\begin{array}{l}\text { Std. Error } \\
\text { Difference }\end{array}$ & $\begin{array}{l}95 \% \mathrm{C} \\
\text { Interva } \\
\text { Differe }\end{array}$ & $\begin{array}{l}\text { dence } \\
\text { the }\end{array}$ \\
\hline \multirow[t]{2}{*}{$\begin{array}{l}\text { Pretest } \\
\text { Score }\end{array}$} & $\begin{array}{l}\text { Equal } \\
\text { variances } \\
\text { assumed }\end{array}$ & 2.932 & .088 & 1.116 & 219 & .266 & 1.413 & 1.266 & -1.082 & 3.909 \\
\hline & $\begin{array}{l}\text { Equal } \\
\text { variances } \\
\text { not } \\
\text { assumed }\end{array}$ & & & 1.120 & 218.396 & .264 & 1.413 & 1.262 & -1.073 & 3.900 \\
\hline
\end{tabular}

The table shows that $t_{\text {calc }}=1.116$ with sig $=0.266>0.05$. The result of calculation at the pre-test session accepts the Null Hypothesis. It confirms that there is no significant difference between the control and experimental group at the pre-test session.

Table 8

Independent samples t-test for post-test score difference

\begin{tabular}{lllllllllll}
\hline \multicolumn{1}{l}{ Level's Test for Equality of Variances } & \multicolumn{1}{l}{ t-test for Equality of Means } & & & \\
\hline & $F$ & Sig. & $\mathrm{t}$ & $\mathrm{df}$ & $\begin{array}{l}\text { Sig. (2- } \\
\text { tailed) }\end{array}$ & $\begin{array}{l}\text { Mean } \\
\text { Difference }\end{array}$ & $\begin{array}{l}\text { Std. Error } \\
\text { Difference }\end{array}$ & $\begin{array}{l}\text { 95\% Confidence } \\
\text { Interval of the } \\
\text { Difference }\end{array}$ \\
\hline $\begin{array}{l}\text { Posttest } \\
\text { Score }\end{array}$ & $\begin{array}{l}\text { Equal } \\
\text { variances } \\
\text { assumed } \\
\text { Equal } \\
\text { variances } \\
\text { not } \\
\text { assumed }\end{array}$ & .002 & .966 & -2.507 & 219 & .013 & -3.409 & 1.360 & -6.089 & -.729 \\
\hline
\end{tabular}

The table shows that $t_{\text {calc }}=2.507$ with sig $=0.013<0.05$. The result of calculation at the post-test session rejects the Null Hypothesis. It confirms that there is a significant difference between the control and experimental group at the post-test session.

\section{Post-Test and Pre-Test Score Difference}

It aims to find out the score difference between the control and experimental group at the time of pre-test and post-time session. It utilizes the Independent Sample T-Test. Table 9 shows the detail of calculation. 
Table 9

$\underline{\text { Pre-test and post-test score difference using independent sample t-test }}$

\begin{tabular}{|c|c|c|c|c|c|c|c|c|c|c|}
\hline & & \multicolumn{2}{|c|}{$\begin{array}{l}\text { Level's Test for } \\
\text { Equality of } \\
\text { Variances }\end{array}$} & \multicolumn{3}{|c|}{ t-test for Equality of Means } & \multirow{3}{*}{$\begin{array}{l}\text { Mean } \\
\text { Difference } \\
\end{array}$} & \multirow{3}{*}{$\begin{array}{l}\text { Std. Error } \\
\text { Difference } \\
\end{array}$} & \multirow{2}{*}{\multicolumn{2}{|c|}{$\begin{array}{l}95 \% \text { Confidence Interva } \\
\text { of the Difference }\end{array}$}} \\
\hline & & $\mathrm{F}$ & Sig. & $\mathrm{T}$ & Df & $\begin{array}{l}\text { Sig. (2- } \\
\text { tailed) }\end{array}$ & & & & \\
\hline & & & & & & & & & Lower & Upper \\
\hline \multirow[t]{2}{*}{$\begin{array}{l}\text { Pre-post } \\
\text { Differences }\end{array}$} & $\begin{array}{l}\text { Equal } \\
\text { variances } \\
\text { assumed }\end{array}$ & 2.946 & .088 & -5.087 & 219 & .000 & -4.823 & .948 & -6.691 & -2.954 \\
\hline & $\begin{array}{l}\text { Equal } \\
\text { variances } \\
\text { not assumed }\end{array}$ & & & -5.059 & 207.508 & .000 & -4.823 & .953 & -6.702 & -2.943 \\
\hline
\end{tabular}

The calculation of post-test and pre-test score difference shows the value of $t_{\text {calc }}=5.087$ and sig $=0.000<0.05$. The result rejects the Null Hypothesis and confirms that there is a significant difference between the control and experimental group. The finding concludes that the poetry appreciation textbook developed within the discussion of character education contributes an effective students' learning outcome, especially in implementing the noble values through literary works.

\section{DISCUSSION}

The article confirms that there is a significant difference in the pre-test and post-test scores between the control and experimental groups, as they received different treatment during the learning process. Meanwhile the control group utilized the conventional textbook, the experimental group utilized another textbook complemented with the character education values. It deploys the Independent Sample T-Test in comparing the pre-test and post-test scores of both groups. The result shows that the experimental group could secure 15.68 in mean value, which is higher than the control group that only afforded 10.86 .

The finding is parallel with (Benninga, Berkowitz, Kuehn, \& Smith, 2003) who found out that the implementation of character education tends to boost the positive development of the elementary students' behavior and academic achievements. In particular, this study focuses on the character education implementation at Higher Education level. It also relates to (Pala, 2011) who investigated the effective guidance of character education in improving the students' sensitivity toward the cognitive development and excellent characters, which include sympathy, respect, responsibility, honesty, fairness, and affection.

During the experiment, there were a few students who found difficulty at the poetry appreciation lecture. The similar issue also appeared in the previous study carried by (Novianti, 2017) who implemented the character education values through a storytelling technique. She found a few students who had problems in identifying the intrinsic and extrinsic elements of novels. The discovery asserts that the students bring their characters in comprehending several particular topics.

Poetry appreciation is a little complicated to comprehend as the literary work generally applies an imaginative sense of interpretation. This study also found a similar issue to (Khatib, 2011) who was stumbled upon a case that most of the students could not dive 
into the deep messages contained by the English poetries. They tended to show a negative response to the literary works by choosing inappropriate dictions. As the solution, the researchers initiated the extra tasks given to the students who experienced the problems aiming to grow their sensitivity to the pieces of literatures.

A textbook offers an important function within the learning process, especially for the conventional classroom design (Lau et al., 2018). It generates a motivation for students in developing the constructive process. Therefore, teachers and lecturers must be aware of the use of a textbook in defining the learning scope, criteria, and activities.

The textbook produced through this experiment offers the implementation of character education values through the poetry appreciation lecture, of which the concept was never adopted at the previous studies. Its content is in accordance with (Yao, Buchanan, Chang, \& Powell-Brown, 2009) who stated that a textbook should provide a room of interpretation within the multiple contexts, such as culture, history, and politics. Both of the studies discussed the development of the textbook, however, contained different objects to the current study.

The use of the textbook for various learning programs at Higher Education level should feature an interesting design and contents of study that aims to improve the promotion of e-textbook in Indonesia and some other countries $(\mathrm{Gu}, \mathrm{Wu}, \& \mathrm{Xu}, 2015)$. The development of e-textbook starts from the preparation of multimedia resources, digital learning sources, and IT integration through a particular learning platform.

The textbook containing character education values is considered as an effective learning instrument at Higher Education level. It is applicable not only for students, but also public use. The dissemination of the textbook represents an attempt to improve the quality of knowledge.

\section{CONCLUSION}

The application of poetry appreciation textbook as the learning instrument for character education implementation is acceptable for the Higher Education students. It enables them to obtain more vivid and larger perception of literature and personality development. The textbook effectiveness has been proved by the Independent Sample $\mathrm{T}$-Test that confirms a significant difference of the mean score between the experimental and control group.

The study briefly implies a constructive learning model as it relies on two subjects, including literature and character development. The complex learning process will provide students with a wider range of improvement to enhance their multiple competencies. Future researchers are expected to hold a gradual development in terms of poetry variations, evaluation, and complement of character education in attempt to improve the teaching and learning outcomes based on the students' need analysis.

\section{REFERENCES}

Bastrukmen, H. (2010). Developing courses in english for specific purpose. New York: Paglave Macmillan. https://doi.org/10.4304/jltr.1.6.918-921 
Battistich, V. (2003). Effects of a school-based program to enhance prosocial development on children's peer relations and social adjustment. Journal of Research in Character Education, 1(1), 1-17.

Benninga, J. S., Berkowitz, M. W., Kuehn, P., \& Smith, K. (2003). The relationship of character education implementation and academic achievement in elementary schools. Journal of Research in Character Education, 1(1), 19-32.

Bier, M. C., \& Berkowitz, M. W. (2004). What works in character education: A research-driven guide for teachers. Washington, DC: Character Education Partnership.

Bodenhorn, N., \& Skaggs, G. (2006). Relationships between implementing character education, student behavior, and student achievement. Journal of Anvanced Academica, $18(1), 82-114$

Brooks, D. (2001). Reading activities for character education: A resourse guide for teacher and student. Petersborough, NH: Cobblestone Publishing. https://doi.org/10.1177/2158244014551709

Brown, H. D. (2001). Teaching by principles an interactive approach to language pedagogy second edition. New York: Logman.

Cohen, L., Manion, L., \& Morrison, K. (2000). Research methods in education. Great Britain: TJ international ltd, padstow, cornwall.

Creasy, K. L. (2008). What is character education? Journal of Education Policy, 3(12), 172-180. https://doi.org/10.4304/jltr.3.6.1128-1134

Cunningworth, A. (2000). Choosing Your Coursebook. Greet Britain: The Bath Press.

Daniel, I. O. A. (2013). Role of parents in literature education among secondary school students: Poetic appreciation as focus. Internasional Journal of Development and Sustainability, 2(1), 116-130.

Djali, \& Muljono, P. (2008). Pengukuran dalam bidang pendidikan. Jakarta: Gransindo.

Erin Katheleen, C. (2010). Definition of a text book. US: eHow. Lnc. Retrieved from http://www.ehow.com/facts 5188705 definition-text-book.html.

Graves, K. (2000). Designing language courses: A guide for teacher. Boston: Heinle \& Heinle Publishers.

Greenberg, M. T., Weissberg, R. P., Brien, M. U. O., Zins, J. E., Fredericks, L., Resnik, H., \& Elias, M. J. (2003). Enhancing school-based prevention and youth development through coordinated social, emotional, and academic learning. American Psychologist, 58(6/7), 466-474. https://doi.org/10.1037/0003-066X.58.6-7.466

Gu, X., Wu, B., \& Xu, X. (2015). Design, development, and learning in e-textbooks: what we learned and where we are going. J. Comput. Educ, 2(1), 25-41. https://doi.org/10.1007/s40692-014-0023-9 
Hoge, J. D. (2002). Character education , citizenship education, and the social studies. Social Studies, 93(3), 103-108. Retrieved from http://dx.doi.org/10.1080/00377990209599891 PLEASE

Howard, R. W., Berkowitz, M. W., \& Achaeffer, E. F. (2004). Politics of character education. Journal of Educational Policy (Vol. 18). Retrieved from https://doi.org./10.1177/0895904803260031

Hunter, L. P. (2000). Birthwork. Pacifica: La Jolla Press.

Kelinger, F. R. (2006). Asas-asas penelitian behaviour. Yogyakarta: Gadjah Mada University Press. https://doi.org/10.5296/jet.v1i2.5153

Khatib, M. (2011). A new approach to teaching english poetry to EFL students. Journal of Language Teaching and Research, 2(1), 164-169. https://doi.org/10.4304/jltr.2.1.164-169

Kirkgoz, Y. (2008). Using poetry as a model for creating english poems. Journal of Language and ILnguistic Studies, 4(2), 94-106.

Koohang, A., Riley, L., Smith, T., \& Schreurs, J. (2009). E-learning and constructivism: from theory to application. Interdisciplinary Journal of E-Learning and Learning Objects, 5, 487-498.

Lau, C., Hung, K., Lam, T., Hon, B., Nkhoma, M., \& Richardson, J. (2018). The role of textbook learning resources in e-learning: A taxonomic study Computers \& Education The role of textbook learning resources in e-learning: A taxonomic study. Computers \& Education, 118, 10-24. https://doi.org/10.1016/j.compedu.2017.11.005

Leming, J. S. (2000). What works in character education: A review of research in the field. Washington, DC: Character Education Partnership.

Lickona, T. (2013). Character matters: How to help our children develop good judgment, intergrity, and essential. New york: A Taochstone Book, Simon \& Schuter. https://doi.org/10.12691/education-5-4-3

Lin, M., Chen, H., \& Sheng Liu, K. (2017). A study of the effects of digital learning on learning Motivation and learning outcome. EURASIA Journal of Mathematics Science $\begin{array}{llll}\text { and Tecnology } & \text { Education, 3553-3564. }\end{array}$ https://doi.org/10.12973/eurasia.2017.00744a

Megawangi, R. (2004). Pendidikan karakter: Solusi yang tepat untuk membangun bangsa. Bogor: Indonesia Heritage Foundation.

Mohammad, R. F., \& Kumari, R. (2007). Effective use of textbooks : A neglected aspect of education in Pakistan. Journal of Education for Internasional Development, 3(1), 112.

Noel, M. D., Daniels, F. M., \& Martins, P. (2015). The future of lecture method as a teaching strategy in community nursing education. Journal of Family Medicine \& Community Health, 2(8), 1-4. 
Novianti, N. (2017). Teaching character education to college students using bildungsromans. International Journal of Instruction, 10(4), 255-272.

Pala, A. (2011). The need for character education. International Journal of Social Sciences and Humanity Studies, 3(2), 23-32.

Pike, M. A. (2017). Christianity and character education: Faith in core value? Journal of Beliefs \& Values: Studies in Religion \& Education, 31(3), 311-312.

Pingel, F. (2010). UNESCO guidebook on textbook research and textbook revision (Second). Paris: United Nations Educational, Scientific and Cultural Organitation.

Pusat Kurikulum. (2010). Pengembangan pendidikan budaya dan karakter bangsa. Jakarta: Pusat kurikulum, Balitbang, Kementrian Pendidikan Nasional.

Richards, J. C. (2001). Curriculum development in language teaching. Cambridge: Cambridge University Press.

Rifai, M. A. (2010). Peningkatan motivasi penulisan dan penerbitan buku akademik di perguruan tinggi. Disampaikan dalam lokakarya penulisan dan penerbitan buku akademik, LPP UNS 2011.

Satriani, I., Emilia, E., \& Gunawan, M. H. (2012). Contextual teaching and learning approach to teaching writing. Indonesian Journal of Aplied Linguistics, 2(1), 10-22.

Sayuti, S. A. (2010). Berkenalan dengan puisi. Yogyakarta: Gama Media.

Schultz, L. H., Barr, D. J., \& Selman, R. L. (2001). The value of a developmental approach to evaluating character development programmes : An outcome study of facing history and ourselves. Journal of Moral Education, 30(1), 3-27. https://doi.org/10.1080/03057240120033

Schultz, L. H., \& Selman, R. (2004). The develompment of psychosocial maturity in young children: A measure for evaluating character education programs. Journal of Research in Character Education, 2(1), 19-44.

Stetson, E., Hurley, A. M., \& Miller, G. E. (2003). Can universal affective education programs be used to promote empathy in elementary aged children? A review of five curricula. Journal of Research in Character Education, 1(2), 129-147.

Sukardi. (2008). Evaluasi pendidikan. Jakarta: Bumi Aksara.

Tomilson, B., Dat, B., Masuhara, H., \& Rubdy, R. (2001). EFL courses for adults. ELT Journal, 55(1), 80-101.

Topalov, J. P., \& Radic-Bojanic, B. B. (2016). Textbooks in the EFL classroom: Defining, assessing and analyzing3. Collection of Paper of The Faculty of Philosopy, XLVI(3), 137-153. https://doi.org/10.5937/ZRFFP46-12094

Vardin, P. (2003). Character education in America. Journal of Montessori Life, 15(2), 32-34. 
Waluyo, H. J. (2002). Apresiasi puisi untuk pelajar dan mahasiswa. Jakarta: Gramedia Pustaka Utama.

Waluyo, H. J. (2010). Pengkajian dan apresiasi puisi. Salatiga: Widya Sari Press.

Yao, Y., Buchanan, D. L., Chang, I. J., \& Powell-Brown, A. (2009). Different drummers : International perspectives on multicultural education. Internastonal Journal of Multicultural Education, 11(2), 1-17. 